\title{
PENGEMBANGAN MEDIA ANIMASI FISIKA PADA MATERI CAHAYA DENGAN APLIKASI FLASH BERBASIS ANDROID
}

\author{
Retno Dian Anggraeni, Rudy Kustijono \\ Jurusan Fisika Universitas Negeri Surabaya \\ retno.dian@gmail.com \\ rudyunesa@gmail.com
}

\begin{abstract}
Abstrak
Telah dilakukan penelitian pengembangan media animasi fisika pada materi cahaya dengan aplikasi flash berbasis Android. Tujuan penelitian adalah untuk mendeskripsikan pengembangan media dan hasil uji coba terbatas media berdasarkan respon guru, peserta didik, dampak, serta kendala. Jenis penelitian yang dilakukan adalah Penelitian dan Pengembangan, dengan langkah penelitian meliputi tahap studi pendahuluan, yaitu studi pustaka, survei lapangan, dan penyusunan draf produk, serta tahap pengembangan dengan uji coba terbatas. Sasaran penelitian adalah proses pembelajaran IPA kelas VIII SMP pada materi cahaya, dengan validasi yang dilakukan oleh tiga ahli media dan ahli materi serta uji coba terbatas dilakukan pada 14 peserta didik kelas VIII SMPN 2 Kota Mojokerto. Hasil dari penelitian ini adalah dalam mengembangkan media animasi fisika dengan aplikasi flash berbasis Android harus memperhatikan: kesesuaian dengan materi, penampilan avatar, kombinasi warna teks dengan background, pergerakan obyek, kemampuan media menyesuaikan ukuran layar, dan penggunaan bahasa. Penilaian dari ahli media dan ahli materi menyatakan bahwa media sangat baik $(91,03 \%)$ ditinjau dari komponen format, isi, kesederhanaan, keterpaduan, keseimbangan, bentuk, dan warna. Respon peserta didik terhadap media adalah sangat baik $(91,72 \%)$, ditinjau dari komponen format, kualitas, kejelasan, serta ketertarikan peserta didik. Media memberikan dampak bagi peserta didik berupa motivasi belajar fisika, pemahaman konsep, serta timbulnya rasa senang. Kendala dalam proses pengembangan yaitu sulit ditemukan referensi software pembuat media, penyesuaian animasi, serta keharusan adanya Adobe AIR dalam perangkat. Tetapi kendala tersebut dapat diatasi dengan mencari referensi dari internet, bertanya dengan ahli, serta melakukan survei lapangan.
\end{abstract}

Kata Kunci : flash, Android, Adobe AIR. 


\section{Pendahuluan}

Belajar adalah suatu proses kompleks yang terjadi pada diri setiap orang sepanjang hidup karena adanya interaksi dengan lingkungannya, oleh karena itu belajar dapat terjadi dimana saja dan kapan saja (Arsyad, 2009) ${ }^{[1]}$. Akhir-akhir ini konsep belajar didekati paradigma konstruktivistik. Woolfolk (2008) ${ }^{[2]}$ mengemukakan bahwa konstruktivisme merupakan pandangan yang menekankan peran aktif peserta didik dalam membangun pemahaman dan memberi makna terhadap informasi. Berdasarkan paradigma tersebut, maka prinsip media mediated instruction menempati posisi strategis dalam mewujudkan ivent belajar secara optimal.

Dalam era perkembangan ilmu pengetahuan dan teknologi yang begitu pesat, profesionalisme guru tidak cukup hanya dengan kemampuan membelajarkan peserta didik, tetapi juga mengelola informasi dan lingkungan untuk memfasilitasi kegiatan belajar, salah satunya dengan memperkaya sumber dan media pembelajaran (Daryanto, 2010) ${ }^{[3]}$. Penjelasan tersebut sesuai dengan PP nomor 74 tahun $2008^{[4]}$ yang menyatakan guru sekurang-kurangnya memiliki kompetensi menggunakan teknologi komunikasi dan informasi secara fungsional. Permendiknas nomor 41 tahun $2007^{[5]}$ menyatakan bahwa RPP disusun dengan mempertimbangkan penerapan teknologi informasi dan komunikasi secara terintegrasi, sistematis, dan efektif sesuai dengan situasi dan kondisi.

Berdasarkan penjelasan di atas, didapatkan bahwa proses pendidikan tidak harus dilaksanakan secara konvensional, namun guru dapat mencari dan mempergunakan alternatif atau sumber belajar lain untuk menjadikan proses belajar mengajar yang awalnya abstrak dan sulit dipahami menjadi sebuah materi yang menarik serta mudah dipahami. Salah satunya yaitu dengan visualisasi materi menggunakan media TIK dalam bentuk animasi dan atau suara. Sajian audio visual akan menjadikan visualisasi menjadi lebih menarik.

Dengan adanya stimulus menarik, maka peserta didik akan mudah dalam memproses informasi yang diterimanya, seperti yang diungkapkan oleh Desmita $(2012)^{[6]}$, bahwa informasi dapat ditransfer menuju memori jangka pendek apabila informasi tersebut mendapat perhatian khusus. Hal penting dalam proses pengolah informasi adalah pemrosesan sendi-sendi (encoding) yang bermakna, yang membutuhkan proses perhatian ke sasaran. Proses penyandian ini merupakan inti dari proses belajar. Kurangnya perhatian menyebabkan informasi tersebut akan hilang.

Stimulus tersebut dapat dikemas dalam suatu media yang dapat mendukung proses belajar dalam memahami konsep tanpa terbatas ruang dan waktu. Sudjana dan Rivai $(2011)^{[7]}$ mengemukakan manfaat media pembelajaran dalam proses belajar peserta didik, diantaranya:

a. Motivasi belajar akan tumbuh dengan pembelajaran yang lebih menarik perhatian.

b. Memungkinkan peserta didik memahami makna dan menguasai bahan pembelajaran, serta mencapai tujuan pembelajaran.

c. Peserta didik tidak bosan dan guru tidak kehabisan tenaga dengan adanya metode mengajar yang bervariasi dan tidak semata-mata komunikasi verbal oleh guru.

d. Peserta didik dapat lebih banyak melakukan kegiatan belajar dan beraktivitas seperti mengamati, melakukan, mendemonstrasikan, memerankan, dan lain-lain.

Dalam membuat atau menetapkan media perlu memperhatikan kriteria pemilihan media. Arsyad (2009) ${ }^{[1]}$ menyampaikan kriteria yang harus diperhatikan diantaranya adalah kesesuaian dengan tujuan yang ingin dicapai, mendukung isi pelajaran, praktis, luwes dan bertahan, keterampilan guru dalam menggunakan, pengelompokkan sasaran,serta mutu teknis. Sedangkan 
Fathurrohman dan Sutikno (2011) ${ }^{[8]}$ menjelaskan beberapa faktor dan kriteria yang harus diperhatikan yaitu obyektifitas, kesesuaian program pengajaran, sasaran program, situasi dan kondisi, serta kualitas teknis.

Salah satu perkembangan ilmu pengetahuan dan teknologi yang dapat dimanfaatkan sebagai media belajar adalah teknologi di bidang komunikasi, yaitu dengan membuat media flash berbasis Android. Android adalah sistem operasi berbasis Linux yang diperuntukkan untuk mobile device. Android merupakan sistem operasi yang paling diminati di masyarakat karena memiliki kelebihan seperti sifat open source yang memberikan kebebasan para pengembang untuk menciptakan aplikasi,sedangkan kekurangannya yakni keterlambatan pengeluaran versi resmi oleh Android serta adanya ancaman malware(http://blogandroidx86.blogspot.co $\mathrm{m})^{[9]}$. Flash adalah gambar bergerak berbentuk dari sekumpulan obyek gambar yang disusun beraturan mengikuti alur pergerakan yang telah ditentukan pada setiap pertambahan waktu (http://kursuskomputerjakarta.com $)^{[10]}$.

Media belajar dengan menggunakan aplikasi flash berbasis Android ini dapat diproduksi dengan menggunakan beberapa program atau software, diantaranya yaitu Flash IDE Pro CS6 untuk mendesain animasi; karakter, dan fitur-fitur di dalam media; FlashDevelop untuk pemrograman; Air Developer Tool (ADT) untuk mempaket aplikasi untuk Android; ActionScript 3.0 sebagai bahasa pemrograman yang dipergunakan; serta Adobe AIR untuk menjalankan aplikasi pada mobile device.

Berdasarkan uraian di atas, peneliti melakukan penelitian pengembangan media animasi fisika pada materi cahaya dengan aplikasi flash berbasis Android. Pertanyaan penelitian yang dapat dikemukakan adalah :

a. Bagaimana mengembangkan media animasi fisika pada materi cahaya dengan aplikasi flash berbasis Android ? b. Bagaimana kelayakan media pembelajaran berupa animasi fisika dengan aplikasi flash berbasis Android pada materi pokok cahaya apabila ditinjau dari respon guru, respon peserta didik, dampak, dan kendala yang terjadi?

\section{Metode Penelitian}

Jenis penelitian yang digunakan adalah jenis penelitian dan pengembangan (Research and Development), yaitu suatu metode penelitian yang digunakan untuk menghasilkan produk tertentu, dan menguji keefektifan produk tersebut (Sukmadinata, 2010) $)^{[11]}$.

Sasaran dari penelitian ini adalah proses pembelajaran IPA di kelas VIII SMP dengan menggunakan aplikasi flash berbasis Android pada materi cahaya, dengan telaah dan validasi yang dilakukan oleh tiga ahli media dan materi serta diujicobakan pada 14 peserta didik kelas VIII SMPN 2 Kota Mojokerto.

Langkah-langkah penelitian dan pengembangan divisualisasikan pada gambar 1.

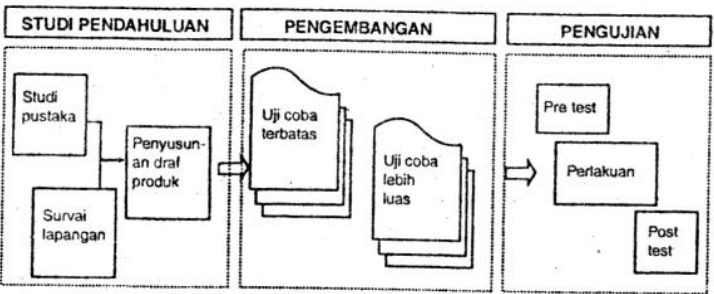

Gambar 1. Langkah-langkah Penelitian dan Pengembangan.

Secara garis besar langkah penelitian yang dilakukan adalah :

a. Studi Pendahuluan yang meliputi studi pustaka, survei lapangan, dan penyusunan draf produk.

b. Pengembangan yang meliputi uji coba terbatas dan uji coba lebih luas.

c. Pengujian yang meliputi pre test, perlakuan, dan post test.

Karena keterbatasan waktu, tenaga, dan biaya, maka penelitian yang dilakukan hanya sampai pada tahap uji coba terbatas. 
Rancangan penelitian yang telah dilakukan adalah sebagai berikut:

a. Studi pendahuluan

- Studi pustaka mengkaji konsepkonsep yang berkaitan dengan penelitian.

- Survei lapangan dilakukan untuk mengumpulkan data yang ada di lapangan berkenaan dengan penelitian.

- Penyusunan draf produk adalah rancangan media yang akan dibuat.

b. Pada tahap pengembangan peneliti membuat instrumen penelitian.

Data yang didapatkan dianalisis dengan statistik yang sesuai dan dideskripsikan apakah media yang dikembangkan layak digunakan atau tidak.

\section{Hasil dan Pembahasan}

Hasil dari penelitian dan pengembangan media yang telah dilakukan adalah sebagai berikut :

a. Studi pendahuluan

- Studi pustaka menghasilkan teori yang berkaitan dengan belajar, pengembangan media, program pembuat media, serta penelitian terdahulu yang relevan.

- Survei lapangan menghasilkan data bahwa terdapat sembilan kelas VIII di SMPN 2 Kota Mojokerto dengan jumlah total peserta didik sebanyak
331, dan terdapat 237 pengguna perangkat Android. Sebagian besar proses belajar dilakukan dengan cara konvensional.

- Penyusunan draf produk adalah penyusunan draf media yang meliputi: penyusunan soal dan materi sesuai dengan standar kompetensi dan kompetensi dasar, penyusunan alur media, pendaftaran fitur-fitur yang dipergunakan, serta memproduksi media.

b. Pada tahap pengembangan peneliti membuat instrumen penelitian, melakukan telaah dan validasi media yang dilakukan oleh ahli media dan ahli materi, serta uji coba terbatas pada 14 peserta didik kelas VIII SMPN 2 Kota Mojokerto.

Secara umum saran yang diberikan oleh ahli media dan ahli materi pada saat telaah adalah menambahkan keragaman background, memperbaiki gradasi warna, memperbaiki dan menambahkan animasi pada konsep cahaya, menambahkan fitur resume dan exit, serta merubah format pertanyaan dalam kalimat negatif menjadi kalimat positif.

Media yang telah memenuhi keriteria selanjutnya divalidasi oleh tiga ahli media dan ahli materi. Hasil validasi media yang dilakukan oleh ahli media dan ahli materi disajikan dalam tabel 1 .

Tabel 1. Hasil Validasi Media oleh Ahli Media dan Ahli Materi

\begin{tabular}{|c|c|c|c|c|c|}
\hline \multirow[t]{2}{*}{ No } & \multirow[t]{2}{*}{ Butir } & \multicolumn{3}{|c|}{$\begin{array}{c}\text { Skor } \\
\text { Validator }\end{array}$} & \multirow{2}{*}{$\begin{array}{c}\text { Rata-rata } \\
\text { Tiap } \\
\text { Komponen }\end{array}$} \\
\hline & & $\mathbf{A}$ & B & $\mathbf{C}$ & \\
\hline \multicolumn{6}{|c|}{ A. FORMAT } \\
\hline 1. & Kejelasan petunjuk penggunaan media & 4 & 3 & 4 & 3,67 \\
\hline 2. & Kesesuaian warna, tampilan gambar, dan tulisan yang ada dalam media & 4 & 3 & 4 & 3,67 \\
\hline \multicolumn{5}{|c|}{ Rata-rata Total Komponen } & 3,67 \\
\hline \multicolumn{6}{|c|}{ B. ISI } \\
\hline 1. & Kesesuaian antara materi cahaya dengan materi dalam media & 3 & 3 & 4 & 3,33 \\
\hline 2. & Kejelasan konsep cahaya yang disampaikan pada media & 3 & 4 & 4 & 3,67 \\
\hline 3. & $\begin{array}{l}\text { Kesesuaian animasi dalam media dengan konsep fisika yang terdapat pada materi } \\
\text { cahaya }\end{array}$ & 3 & 4 & 4 & 3,67 \\
\hline 4. & Kejelasan animasi dalam menyampaikan konsep fisika & 4 & 3 & 4 & 3,67 \\
\hline \multicolumn{5}{|c|}{ Rata-rata Total Komponen } & 3,58 \\
\hline \multicolumn{6}{|c|}{ C. BAHASA } \\
\hline 1. & Kebakuan bahasa yang digunakan & 3 & 4 & 3 & 3,33 \\
\hline 2. & Kemudahan dalam memahami bahasa yang digunakan & 4 & 4 & 3 & 3,67 \\
\hline 3. & Keefektifan kalimat yang digunakan & 4 & 3 & 3 & 3,33 \\
\hline
\end{tabular}




\begin{tabular}{|c|c|c|c|c|c|}
\hline \multirow{2}{*}{$\begin{array}{c}\text { No } \\
4 .\end{array}$} & \multirow{2}{*}{$\begin{array}{c}\text { Butir } \\
\text { Penggunaan kata sesuai dengan Ejaan Yang Disempurnakan (EYD) }\end{array}$} & \multicolumn{3}{|c|}{$\begin{array}{c}\text { Skor } \\
\text { Validator }\end{array}$} & \multirow{2}{*}{$\begin{array}{c}\text { Rata-rata } \\
\text { Tiap }\end{array}$} \\
\hline & & 3 & 3 & 4 & \\
\hline \multicolumn{5}{|c|}{ Rata-rata Total Komponen } & 3,42 \\
\hline \multicolumn{6}{|c|}{ D. KESEDERHANAAN } \\
\hline 1. & Animasi dalam media sederhana & 4 & 4 & 4 & 4,00 \\
\hline 2. & Animasi dalam media mudah dimengerti & 4 & 4 & 4 & 4,00 \\
\hline 3. & Animasi yang disajikan dalam media sesuai dengan karakteristik peserta didik & 4 & 3 & 4 & 3,67 \\
\hline 4. & Kalimat yang digunakan mudah dimengerti & 4 & 4 & 3 & 3,67 \\
\hline \multicolumn{5}{|c|}{ Rata-rata Total Komponen } & 3,84 \\
\hline \multicolumn{6}{|c|}{ E. KETERPADUAN } \\
\hline 1. & Urutan antar fase di dalam media sudah sesuai & 3 & 3 & 4 & 3,33 \\
\hline 2. & Petunjuk yang digunakan dalam media sudah sesuai & 4 & 4 & 4 & 4,00 \\
\hline \multicolumn{5}{|c|}{ Rata-rata Total Komponen } & 3,66 \\
\hline \multicolumn{6}{|c|}{ F. KESEIMBANGAN } \\
\hline 1. & Ukuran animasi dan tulisan pada tiap fase di dalam media sesuai & 4 & 3 & 4 & 3,67 \\
\hline 2. & Ukuran gambar pada tiap fase di dalam media sesuai & 4 & 3 & 4 & 3,67 \\
\hline 3. & Tata letak tulisan pada tiap fase di dalam media seimbang & 4 & 3 & 4 & 3,67 \\
\hline 4. & Tata letak gambar pada tiap fase di dalam media seimbang & 3 & 3 & 4 & 3,33 \\
\hline \multicolumn{5}{|c|}{ Rata-rata Total Komponen } & 3,58 \\
\hline \multicolumn{6}{|c|}{ G. BENTUK } \\
\hline 1. & Animasi yang digunakan di dalam media menarik & 4 & 3 & 4 & 3,67 \\
\hline 2. & Bentuk huruf mudah dibaca & 4 & 4 & 4 & 4,00 \\
\hline \multicolumn{5}{|c|}{ Rata-rata Total Komponen } & 3,84 \\
\hline \multicolumn{6}{|c|}{ H. WARNA } \\
\hline 1. & Warna tiap halaman sesuai & 4 & 3 & 4 & 3,67 \\
\hline 2. & Gradasi warna sudah sesuai & 4 & 3 & 4 & 3,67 \\
\hline \multicolumn{5}{|c|}{ Rata-rata Total Komponen } & 3,67 \\
\hline
\end{tabular}

Berdasarkan data di atas tampak bahwa penilaian yang diberikan oleh ahli media dan ahli materi adalah sangat baik $(91,03 \%)$. Hal tersebut menunjukkan bahwa pengembangan media ini telah memenuhi beberapa kriteria media yang dapat dijelaskan sebagai berikut:

a. Format: petunjuk penggunaan dalam suatu media merupakan salah satu hal yang penting diperhatikan. Penampilan menarik dan bahasa yang persuasif menjadi nilai positif. Karakteristik tersebut ditunjukkan pada gambar 2 .

b. Isi: soal dan materi yang diberikan di dalam media harus sesuai dengan kurikulum. Di dalam media ini, soal dan materi diurut sesuai dengan standar kompetensi dan kompetensi dasar materi cahaya kelas VIII SMP yang disertai dengan pemberian poin atau skor akhir. Pemberian poin pada jawaban benar dan skor akhir merupakan penguatan positif yang dapat memberikan motivasi bagi peserta didik.Karakteristik tersebut diperlihatkan pada gambar 3 .

c. Bahasa: penggunaan bahasa dalam media harus memperhatikan kebakuan dan keefektifan kalimat agar mudah dimengerti. Soal-soal di dalam media dibuat dalam kalimat positif.

d. Kesederhanaan: kesesuaian animasi dengan peserta didik dan materi harus diperhatikan dalam pengembangan media. Animasi yang sesuai akan menunjang pemahaman peserta didik. Karakteristik tersebut diperlihatkan pada gambar 4.

e. Keterpaduan: soal dan materi di dalam media dipadukan dan diurut sesuai dengan standar kompetensi dan kompetensi dasar. Karakteristik tersebut ditunjukkan pada gambar 5.

Tampilan media Physics Run:

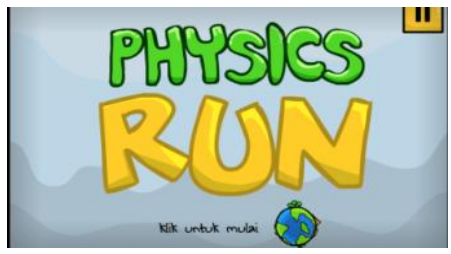

Gambar 2a. Tampilan awal media. 


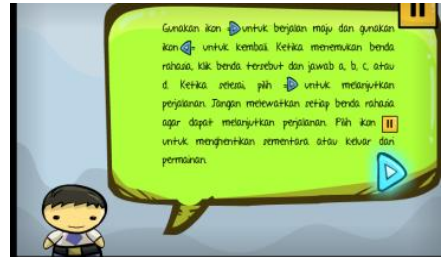

Gambar 2b. Tampilan petunjuk penggunaan media.

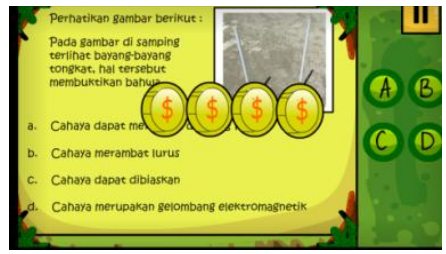

Gambar 3a. Tampilan saat jawaban benar.

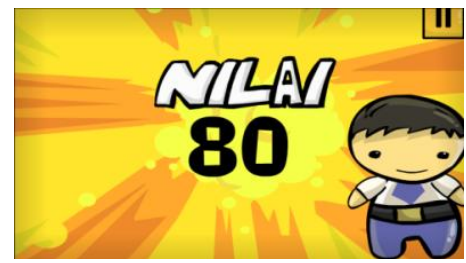

Gambar 3b.Tampilan skor akhir.

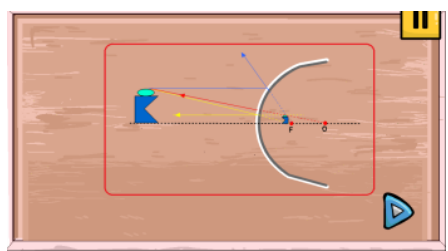

Gambar 4. Tampilan animasi materi lensa cembung

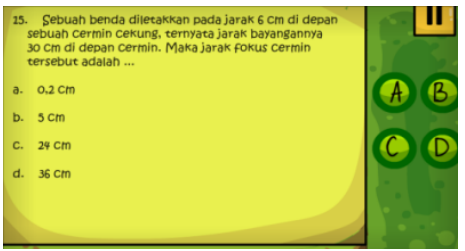

Gambar 5a. Tampilan soal

f. Keseimbangan: pengembangan media harus memperhatikan penataan animasi dan tulisan pada tiap halamannya. Penggunan tata letak dan ukuran yang sesuai membuat media terlihat rapi, terstruktur, dan menarik. Karakteristik tersebut diperlihatkan pada gambar 6 .

g. Bentuk: bentuk animasi dan huruf yang digunakan di dalam media harus dipertimbangkan, tidak hanya dari segi

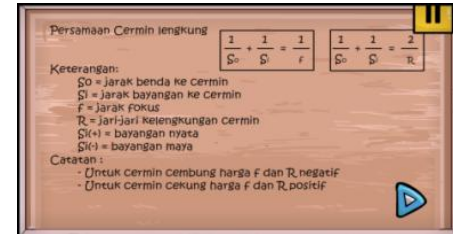

Gambar 5b. Tampilan soal dan materi yang berurutan.

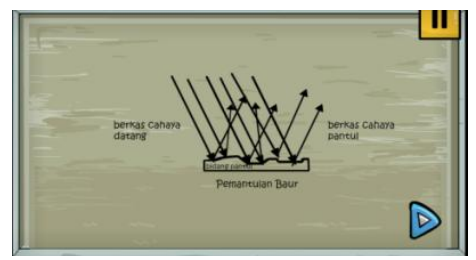

Gambar 6. Tampilan salah satu animasi materi pemantulan.
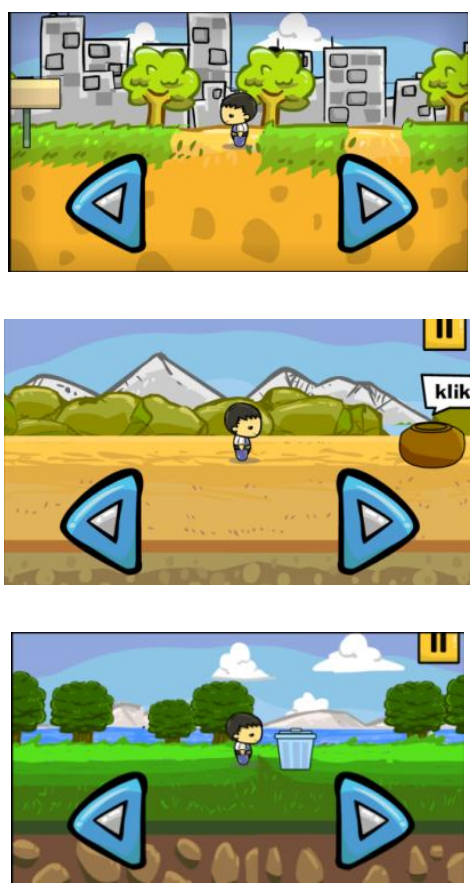

Gambar 7. Tampilan beberapa background media.

keindahan namun dari segi kejelasan dan keterbacaan teks.

h. Warna: pengembangan media harus memperhatikan gradasi warna pada fiturfitur yang digunakan agar tidak mempersulit pengguna. Karakteristik tersebut diperlihatkan pada gambar 7 .

Hasil uji coba terbatas media kepada 14 peserta didik disajikan dalam tabel 2. 
Tabel 2. Hasil Respon Peserta Didik pada Uji Coba Terbatas

\begin{tabular}{|c|c|c|c|c|c|c|}
\hline \multirow{3}{*}{ No } & \multirow{3}{*}{ Indikator } & \multicolumn{4}{|c|}{ Penilaian } & \multirow{3}{*}{$\begin{array}{c}\text { Rata-rata } \\
\text { Tiap } \\
\text { Komponen }\end{array}$} \\
\hline & & SS & $\mathbf{S}$ & TS & STS & \\
\hline & & 4 & 3 & 2 & 1 & \\
\hline \multicolumn{7}{|c|}{ A. FORMAT MEDIA } \\
\hline 1. & Sistematika penyajian materi mudah dipahami & 10 & 4 & & & 3,71 \\
\hline 2. & Petunjuk pengoperasian media mudah dipahami & 11 & 3 & & & 3,78 \\
\hline \multicolumn{6}{|c|}{ Rata-rata Total Komponen } & 3,74 \\
\hline \multicolumn{7}{|c|}{ B. KUALITAS MEDIA } \\
\hline 1. & Penyajian tampilan (gambar, warna, animasi, dll) yang ada menarik & 7 & 6 & 1 & & 3,43 \\
\hline 2. & Penyajian audio mendukung tampilan media & 10 & 4 & & & 3,71 \\
\hline 3. & Tampilan tulisan pada media mudah dibaca & 13 & 1 & & & 3,93 \\
\hline \multicolumn{6}{|c|}{ Rata-rata Total Komponen } & 3,69 \\
\hline \multicolumn{7}{|c|}{ C. KEJELASAN MEDIA } \\
\hline 1. & Materi yang disajikan mudah dipahami & 11 & 3 & & & 3,78 \\
\hline 2. & Gambar yang ada membantu pemahaman materi & 10 & 4 & & & 3,71 \\
\hline 3. & Bahasa yang digunakan dalam media mudah dipahami & 10 & 4 & & & 3,71 \\
\hline \multicolumn{6}{|c|}{ Rata-rata Total Komponen } & 3,73 \\
\hline \multicolumn{7}{|c|}{ D. KETERTARIKAN PESERTA DIDIK } \\
\hline 1. & Saya lebih termotivasi belajar fisika dengan menggunakan media ini & 8 & 6 & & & 3,57 \\
\hline 2. & Media ini membantu saya dalam memahami konsep fisika & 6 & 8 & & & 3,43 \\
\hline 3. & Belajar dengan menggunakan media ini lebih menyenangkan & 8 & 6 & & & 3,57 \\
\hline \multicolumn{6}{|c|}{ Rata-rata Total Komponen } & 3,52 \\
\hline
\end{tabular}

Berdasarkan data di atas tampak bahwa respon peserta didik terhadap media sangat baik $(91,72 \%)$. Hal tersebut menunjukkan bahwa media ini telah memenuhi beberapa kriteria media yang dapat dijelaskan sebagai berikut:

a. Format media: pengembangan media ini telah disesuaikan dengan standar kompetensi dan kompetensi dasar materi cahaya pada kelas VIII SMP, sehingga materi di dalam media terstruktur dan mudah dipahami.

b. Kualitas media: pengembangan media memperhatikan kualitas teknik audio dan visual yang dipilih dengan penyesuaian tingkat perkembangan peserta didik dan materi.

c. Kejelasan media: pengembangan media ini telah mempertimbangkan aspek keefektifan media yang ditunjukkan dengan kemudahan media dalam menyampaikan pesan dalam bentuk tulisan maupun animasi.

d. Ketertarikan peserta didik: pengembangan media ini memberikan kontribusi dalam meningkatkan sikap positif peserta didik seperti: motivasi belajar fisika, mudah dalam memahami konsep, serta timbulnya rasa senang pada saat belajar dengan media.
Peneliti mengalami beberapa kendala selama proses pengembangan media, diantaranya: kesulitan dalam mencari referensi untuk software pembuat media yang masih tergolong baru dan belum banyak pengguna, kesulitan dalam penyesuaian animasi dengan tingkat perkembangan peserta didik, dan kendala teknis dalam instalasi media dimana tidak semua perangkat yang digunakan oleh peserta didik sudah terdapat Adobe AIR. Namun, kendala tersebut dapat diatasi dengan cara mencari referensi di internet, menanyakan kepada para ahli, dan melakukan survei lapangan.

\section{Simpulan}

a. Untuk mengembangkan media animasi fisika dengan aplikasi flash berbasis Android ada beberapa karakteristik yang harus diperhatikan meliputi: kesesuaian penggunaan animasi dan gambar dengan materi, penampilan avatar yang menunjukkan karakter peserta didik, pemilihan kombinasi warna latar belakang, pergerakan animasi, penampilan bentuk dan warna teks, penggunaan bahasa sesuai dengan EYD dan komunikatif, serta kemampuan media menyesuaikan ukuran layar. 
b. Hasil validasi yang dilakukan oleh ahli media dan ahli materi menyatakan media sangat baik $(91,03 \%)$, ditinjau dari komponen format, isi, kesederhanaan, keterpaduan, keseimbangan, bentuk, dan warna. Respon peserta didik terhadap media adalah sangat baik (91,72\%), ditinjau dari komponen format, kualitas, kejelasan, serta ketertarikan peserta didik terhadap media. Media ini memberikan dampak bagi peserta didik berupa motivasi belajar fisika, pemahaman konsep, serta timbulnya rasa senang. Kendala dalam proses pengembangan yaitu sulitnya ditemukan referensi software pembuat media, penyesuaian animasi, serta keharusan adanya Adobe AIR. Tetapi kendala tersebut dapat diatasi dengan mencari referensi dari internet, bertanya dengan ahli, dan melakukan survei lapangan.

\section{Daftar Pustaka}

[1]Arsyad, Azhar. 2009. Media Pembelajaran. Jakarta: Rajawali Pers.

[2]Woolfolk, Anita. et al. 2008. Psychology in Education. England: Pearson.

[3]Daryanto. 2010. Media Pembelajaran. Yogyakarta: Gava Media.

[4]PP nomor 74 tahun 2008.

[5]Permendiknas nomor 41 tahun 2007.

[6]Desmita. 2012. Psikologi Perkembangan. Bandung: Remaja Rosdakarya.

[7]Sudjana, Nana dan Rivai, Nana. 2011. Media Pengajaran. Bandung: Sinar Baru Algensindo.

[8]Fathurrohman, Pupuh dan Sutikno, Sobry. 2011. Strategi Belajar Mengajar. Bandung: Refika Aditama.

[9](http://blogandroidx86.blogspot.com).

[10](http://kursuskomputerjakarta.com).

[11]Sukmadinata, Nana Syaodih. 2010. Metode Penelitian Pendidikan. Bandung: PT. Remaja Rosdakarya. 